Ensino, Saúde e Ambiente-Vs (1), pp. $26-56, \mathcal{A} 6$ ril, 2015

\title{
“TITIA VEM CÁ VER A PEDRA ALUMIANTE QUE O PAPAI TROUXE" - HISTÓRIA DA CIÊNCIA, RADIOATIVIDADE E O CÉSIO-137 EM GOIÂNIA: PROPOSTAS PARA UMA UNIDADE DIDÁTICA
}

\author{
HISTORY OF SCIENCE, RADIOACTIVITY AND CESIUM-137 IN \\ "GOIÂNIA": A PROPOSAL FOR TEACHING UNIT
}

Paulo César Gomes, Jair Lopes Júnior, Regiane Delarole

Universidade Estadual Paulista - UNESP

\begin{abstract}
RESUMO
O estudo objetivou discutir contribuições da história da ciência recente ao ensino de química tendo como temática a estruturação de uma unidade didática sobre o acidente do césio-137 em Goiânia - Goiás, Brasil (1987-2007). Tratou-se de uma Pesquisa Qualitativa na qual pesquisador e professor adotaram a utilização da metodologia do Ensino por Investigação na qual os alunos deveriam buscar informações, organizar dados coletados, formular hipóteses e estabelecer relações. Dentro da linguagem dos quadrinhos, os alunos produziram cartazes para uma exposição na escola sobre o vigésimo aniversário do acidente. Os resultados demonstraram que este recurso possibilitou explorar a riqueza de detalhes nas ilustrações utilizadas. A linguagem dos quadrinhos é integrante do cotidiano dos alunos e eles têm facilidade em expor suas ideias através dela. A exposição dos cartazes sobre a temática denotou o grande interesse dos alunos em realizar e participar de todas as atividades propostas.
\end{abstract}

Palavras-chave: história da ciência, radioatividade, césio-137.

\begin{abstract}
This study aimed to discuss the recent contributions of History of Science to the teaching of chemistry. The theme of the teaching unit was on the accident of cesium137 in Goiânia - Goiás, Brazil (1987). This was a qualitative study in which researcher and professor use the methodology of teaching on research. Thus, students should seek information, organize the data collected and establish relationships. Students produced posters in an exhibition at the school on the twentieth anniversary of the accident. Results demonstrated the importance of this resource. It was possible to exploit the abundance of detail and illustrations utilized what themes they students consider important and which they exploited. A poster exhibition on the theme indicated the strong interest of students to participate in all activities proposed. The study also revealed the importance of using elements of the History of Science in Chemical Education and its relationship to the daily life of students.
\end{abstract}

Key words: history of science; radioactivity; cesium-137 


\section{INTRODUÇÃO}

Poderia a História recente contribuir com a Educação para a Ciência? De acordo com Beltran e Ciscato (2003) aprender noções básicas sobre Química favorece e instrumentaliza as pessoas a, primeiro, exigir as benfeitorias das inúmeras aplicações do conhecimento químico. Em segundo, justificam os autores, ajudaria os sujeitos a situarem-se acerca dos problemas socioambientais, discutirem os numerosos problemas da vida contemporânea além de saber relacionar este conhecimento com o cotidiano.

Um exemplo destes problemas é o recente escândalo da contaminação do leite e seus derivados por melamine na China, em 2009. "causou a morte de pelo menos seis crianças e deixou outras 300 mil doentes" (BBC NEWS, 2009). Algo semelhante ocorreu com o leite no Brasil em 2007. São fatores que remetem a juízos e compreensão sobre a química que impulsionam problemas e também soluções em diferentes setores: poluição e produção lixo, segurança ambiental, uso racional de reservas minerais e recursos naturais pela indústria e comunidade, produção de energia, uso da biotecnologia, saúde alimentar e conservação de alimentos, indústria de medicamentos e cosméticos, entre tantos outros usos.

Como já se poderia prever para 2007, foi um ano que teve, especialmente em seu segundo semestre, seus noticiários invadidos por manchetes e reportagens na mídia acerca do $20{ }^{\circ}$ aniversário do primeiro acidente radioativo, na data de 13 de setembro de 1987, em Goiânia - Estado de Goiás, no Brasil. Pouco mais de dezesseis meses separam o acidente ocorrido na Usina Nuclear, Estação 4, em proporções imensamente maiores em Chernobyl, Ex-URSS, atual Ucrânia, do acidente no Estado de Goiás. Infelizmente, não há nada para ser comemorado, pelo contrário (GREENPEACE, 2010c; OLIVEIRA, 2007; SILVA, 2007; CHAVES, 2007). É preciso ponderar sobre alguns aspectos: o que contribuiu para a ocorrência do acidente? Quais fatos foram subsequentes ao acidente? Qual foi e qual é a situação das vítimas? Qual foi a posição da Justiça Pública? Quais são as possíveis contribuições do episódio do Césio-137 ao Ensino de Química? Antes de tratar destas contribuições, serão revistos alguns aspectos históricos da radioatividade na História da Ciência.

Historicamente, o termo radioatividade foi cunhado e difundido primeiramente pela francesa Maria Sklodowska Curie (1867-1934), ou simplesmente Marie Curie. Pelo menos é o que aponta com propriedade o artigo "Como Becquerel Não Descobriu A Radioatividade" (MARTINS, 1990). Marie Sklodowska, de nacionalidade polonesa, 
imigrou juntamente com sua irmã para a França, onde pode cursar Física e Matemática. Aos 27 anos, conheceu Pierre Curie com quem se casou e teve duas filhas (QUINN, 1997). A união do casal foi decisiva para o sucesso da vida acadêmica de ambos. Atuando em um precário ambiente de trabalho, o casal Curie conseguiu investigar e obter êxito em muitas de suas pesquisas.

Segundo Fröman (1996), Marie Curie foi pioneira em todos os sentidos na História da Ciência. Primeiro, pelos preconceitos em relação à questão do gênero, já que a sociedade da época restringia o acesso de mulheres a determinados espaços para a produção de pesquisas no campo das ciências e mesmo em universidades. Marie e Pierre Curie, em 1903, ganharam o prêmio Nobel em Física por suas pesquisas sobre a radioatividade, dividido com o francês Becquerel.

Tal prêmio é fruto de trabalhos do casal Curie realizados em péssimas condições ambientais num galpão, os dados compuseram a tese de Doutorado de Marie. Eles fizeram inúmeras pesquisas com a radioatividade e investigaram seus fenômenos. Descobriu partículas emitidas pelo núcleo radioativo (nomeadas mais tarde, por alfa, beta e gama). Deste modo, a própria Marie Curie afirma (1899), sobre os fenômenos investigados pelo também cientista francês Henry Becquerel:

Os raios urânicos foram frequentemente chamados de raios de Becquerel. Pode-se generalizar-se esse nome, aplicando-o não apenas aos raios urânicos mas também aos raios tóricos e todas as radiações semelhantes. Chamarei de radioativas as substâncias que emitem raios de Becquerel. O nome de hiperfosforescência, que foi proposto para o fenômeno, parece-me dar-me uma falsa ideia de sua natureza. (CURIE ${ }^{1}, 1899$, apud in MARTINS, 1990, grifos da autora)

Martins (1990) aponta que Becquerel não fez quaisquer relações ou investigações mais aprofundadas sobre o fenômeno que tinha diante de si. Neste sentido, denota as afirmações e relações elaboradas de Becquerel em relação à emissão de partículas foram inconsistentes com os trabalhos desenvolvidos posteriormente pelo casal Curie (MARTINS, 1990). Apesar das controvérsias históricas sobre a autoria da descoberta da radioatividade, certamente não foi Becquerel quem mereceu a exclusividade de seus créditos.

É notória a presença de Marie na História das Ciências. Marie foi a primeira mulher a receber a duas premiações do Nobel por suas pesquisas científicas, também

\footnotetext{
${ }^{1}$ CURIE, P.; CURIE, M. S. Sur la radioactivité provoquée par les rayons de Becquerel. Comptes Rendus, v. 129, p. 714-716, 1899.
} 
primeira mulher a ingressar como professora na Universidade de Sorbonne, na França (PASACHOFF, 1996). Em 1911, em Química, ela recebeu outro prêmio Nobel pela descoberta dos elementos Rádio e Polônio. Marie Curie trabalhou com seu marido Pierre Curie e publicaram muitos trabalhos conjuntamente. Marie Curie foi hospitalizada e morreu vítima de leucemia, possivelmente após sua contínua exposição à radiação que exaustivamente pesquisara (PASACHOFF, 1996). Segundo Fröman (1996), o marido Pierre também apresentava os sintomas de exposição à radiação, entretanto, sua morte foi antecipada por ter o crânio esmagado por uma carruagem em um acidente.

Os trabalhos do casal Pierre e Marie Curie deixaram um legado para que Ernest Rutherford e Frederick Soddy pudessem elucidar nas décadas seguintes diversas propriedades de elementos radioativos e da radioatividade (MERÇON; QUADRAT, 2004). Estes autores também discorrendo sobre a História do Tempo Presente, isto é, acontecimentos posteriores à segunda metade do século XX, fazem uma apresentação histórica cronológica de eventos da II Guerra Mundial, o projeto Manhattan, a Guerra Fria das usinas e acidentes nucleares.

Segundo Vizentini ${ }^{2}$ (2000, apud in MERÇON; QUADRAT, 2004), a Alemanha Nazista já havia se rendido antes do primeiro teste nuclear. O Japão possivelmente seria derrotado com armamentos convencionais, deste modo, assegura o historiador, a explosão das bombas nucleares no Japão foi apenas uma demonstração de poderio militar dos USA para as outras potências militares, inclusive para a ex-URSS.

\section{RADIOISÓTOPOS DE CÉSIO E O CLORETO DO CÉSIO-137}

Foram retomados aqui alguns conceitos químicos. Criado em 1913 pelo químico inglês Frederick Soddy (1877-1956), os termos isótopo e isotopia foram utilizados para designar as diferentes espécies do mesmo elemento químico. Assim, isótopos são átomos de um mesmo elemento químico, por possuírem o mesmo número de prótons no núcleo atômico, mas com massas atômicas diferentes ou, de outro modo, a somatória de prótons e nêutrons no núcleo atômico resultam diferentes massas.

Sabe-se, atualmente, que existem isótopos na natureza de quase todos os elementos químicos (substâncias presentes em minerais e na atmosfera). A exemplo disso, o elemento químico hidrogênio e seus três isótopos: (1) o hidrogênio,

\footnotetext{
${ }^{2}$ VIZENTINI, P. G. F. A Guerra Fria. Em: REIS FILHO, D.A. (Org.). O Século XX. Rio de Janeiro: Civilização Brasileira, 2000.
} 
propriamente dito, também conhecido por prótio, de massa $\mathrm{A}=1$ ( $\mathrm{A}=$ unidade de massa atômica); (2) o deutério: com $\mathrm{A}=2$, constituinte da água pesada (empregada na refrigeração de reatores nucleares e também deu origem às bombas de hidrogênio, é radioativo); e o trítio, com $\mathrm{A}=3$, este é instável e também radioativo. A representação deles é dada respectivamente por ${ }^{1} \mathrm{H}_{1},{ }^{2} \mathrm{H}_{1},{ }^{3} \mathrm{H}_{1}$ (FELTRE, 2004; MORTIMER et al., 2000). Dada a definição de isotopia, um radioisótopo é “[...] um elemento que tem uma configuração no seu núcleo que o torna instável e que tende à estabilização pela emissão de radiação" (IPEN/2006).

O elemento Césio foi descoberto por análise espectrográfica de uma água mineral pelos pesquisadores Robert Wilhelm Bunsen e Gustav Kirchhoff em 1860, em Dürkheim, Alemanha. Césio, do latim, Caesium significa 'azul da cor do céu'. Atendendo a uma grande demanda de informações após o acidente em Goiânia e Chernobyl, Collins et al. (1988) elaboraram um detalhado artigo publicado na Revista Química Nova, intitulado “O que é césio-137?” acerca das propriedades suas físicoquímicas, comportamento no corpo humano e no ambiente. Desta forma, denotam as autoras:

O césio-137 é um radionucleotídeo produzido a partir da fissão do urânio que se desintegra emitindo partículas betas, elétrons e raios gama. Ele é usado [...] como fonte de raios gama na indústria e nas irradiações terapêuticas. (COLLINS et al., 1988)

No mesmo artigo, as autoras fornecem inúmeras informações sobre como se dá produção do cloreto de césio $\left({ }^{137} \mathrm{CsCl}\right)$, uma substância higroscópica - que se adere à água, inclusive àquela presente na umidade do ar - e fluorescente, obtido eficientemente a partir da fissão de: urânio-233, urânio-235 ou plutônio-239. Ressaltaram ainda, que na natureza existe apenas um nuclídeo estável do Césio, o ${ }^{133} \mathrm{Cs}_{55}$, composto por um núcleo com 55 prótons e 78 nêutrons. Informaram ainda que até a data eram conhecidos 34 isótopos todos radioativos ou instáveis do ${ }^{133} \mathrm{Cs}_{55}$. O Césio-137 se desintegra por dois caminhos na formação do elemento bário (COLLINS et al., 1988).

\section{UTILIZAÇÃO DA RADIOATIVIDADE E RESERVAS MINERAIS DE URÂNIO}

Este artigo não trata dos bons ou maus usos das descobertas científicas, mas também poderia. Os usos atuais da radioatividade, segundo o Instituto de Física da UFRJ (IF/UFRJ), estão dirigidos em basicamente três principais: “(1) uso da energia do núcleo do átomo; (2) uso das radiações que têm a capacidade de atravessar a matéria e 
velar filmes (raios X); (3) uso da capacidade (radioterapia ou esterilização de material médico)" (IF/UFRJ, 2010). O primeiro uso mencionado pelo IF/UFRJ refere-se ao beneficiamento de algum dos elementos químicos radioativos com grandes liberações de energia, por exemplo, na produção de eletricidade - e também alto poder de destruição como, por exemplo, sua utilização nas bombas das cidades japonesas de Hiroshima e Nagasaki, II Guerra Mundial em 1945. Estima-se que estas bombas, de urânio em Hiroshima e de plutônio em Nagasaki, tenham provocado de uma só vez a morte de, respectivamente, 80 mil e 40 mil pessoas em cada uma destas duas cidades (MERÇON; QUADRAT, 2004). Trata-se de uma estimativa porque o número de mortos tende a variar entre os muitos autores e historiadores. Outro fator importante são os óbitos não contabilizados - decorrentes da contínua exposição à radiação ou de inúmeras doenças provocadas por esta.

O elemento urânio é principalmente extraído de minérios com propriedades radioativas naturais. As principais reservas do minério uraninita no mundo estão distribuídas nos continentes: África (Nigéria, Gabão, Congo, Namíbia e África do Sul), América do Norte (Estados Unidos e o Estado do Alasca, Canadá), Oceania (Austrália e Ilha Tasmânia), Ásia (Rússia, Kazaquistão, Uzbequistão e outros), Europa (França) e América do Sul. No Brasil, os principais Estados produtores são: Ceará (142 mil toneladas); Bahia (93.200 toneladas); Minas Gerais (100 mil toneladas). Há, porém, segundo o IPEN (2006) outras jazidas menores nos Estados da Paraíba, Paraná, Pará e Goiás. Segundo as Indústrias Nucleares do Brasil S.A., o Brasil ocupa a sexta posição no ranking mundial de reservas de urânio (algo em torno de 309.000 toneladas de $\mathrm{U}_{3} \mathrm{O}_{8}$ - Triuranium octoxide). Algumas localidades no interior do sertão cearense brasileiro tiveram sua realidade econômica e social literalmente transformada com a extração do minério uraninita (ABEN, 2010).

A radioatividade se utilizada de forma controlada, além da energia elétrica, tem atualmente utilidade em vários setores - (a) Medicina: radiografias (raios-X); radioterapia (tratamento de tumores); nuclear (mapeamento de absorção de substância); (esterilização) materiais e equipamentos; (b) Indústria: mecânica de peças (diagnóstico de defeitos em peças internas em máquinas e equipamentos); (c) alimentícia (conservação e prolongamento do armazenamento de frutos); (d) agricultura: entomologia controle (extermínios de pragas na agricultura por controle biológico de 
pragas a partir da técnica de esterilização de machos); (e) Produção e geração de Energia: eletricidade (Instituto de Física/UFRJ, 2010).

O urânio proveniente destas reservas, depois de processado e beneficiado em países que possuem tal tecnologia, tem sido frequentemente utilizado em usinas nucleares, em testes nucleares e ampliação do poderio bélico nuclear de muitos países. Existem no mundo atualmente, segundo a Global Security Newswire em dados de 2008, cinco grandes 'potências nucleares declaradas' com poderio ofensivo bélico nuclear. Elas são: Estados Unidos da América (USA), Rússia, Reino Unido, França e China. Há também as chamadas potências nucleares autodeclaradas: Coréia do Norte, Índia e Paquistão. Por último, as potências nucleares: Israel e Irã.

Por outro lado, há o comprometimento de alguns dos países envolvidos em acordos e políticas internacionais em prol da redução dos projetos que envolvam a redução de armamentos nucleares e utilização da energia nuclear para fins pacíficos iniciativa de 1991 - Tratado de Redução de Armas Estratégicas. Então, desde 1991, houve a rompimento do acordo por alguns países e descumprimento de políticas acordadas, pois produziram armas e realizaram testes. Um exemplo disto, é que vem sendo feitos testes nucleares pela Coréia do Norte e ainda existem grandes impasses com o enriquecimento do urânio pelo Irã, que vem sofrendo sanções econômicas (LIBÉRATION.FR, 2009; SABATINI, 2010).

Obama e Medvedev, respectivamente, atuais presidentes dos USA e Rússia, encontraram-se em Praga buscando firmar o acordo, o Strategic Arms Reduction Talks 2 (START 2). Este acordo, segundo Semo (2010), objetivou: a redução de $30 \%$ do armamento bélico nuclear; em resumo, de 2200 para 1500 ogivas nucleares; de 800 para 700 mísseis intercontinentais presentes em submarinos e bombardeiros (os números iniciais foram previstos pelo Tratado de Moscou, assinado em 2002). Além da redução dos testes nucleares realizados nestes dois países (SEMO, 2010). No Brasil, o Governo Federal, segundo o Ministério de Minas e Energia, é meta até 2030 ampliar de 3\% para $5 \%$ as usinas nucleares nas regiões Nordeste e Sudeste - incluindo a ativação de Angra III, pois o "[...] programa nuclear apresenta o grande diferencial de não emitir gases causadores do efeito estufa" (MEC, 2007).

\section{CONTRIBUIÇÕES DO EPISÓDIO EM GOIÂNIA AO ENSINO DE QUÍMICA}

Ao investigar concepções de alunos do Curso da Licenciatura em Química, é ressaltado que os alunos “[...] não podem negligenciar a temática da Química Ambiental 
na sua profissão, dada a necessidade de educar ambientalmente por meio da química". (CORTES JÚNIOR et al, 2009). Os documentos oficiais ressaltam que...

As características comuns à Biologia, à Física à Química e à Matemática, recomendam uma articulação didática e pedagógica interna à sua área, na condução do aprendizado, em salas de aula ou em outras atividades dos alunos. Procedimentos metodológicos comuns e linguagens compartilhadas permitem que as competências gerais, traduzidas para a especificidade da área, possam ser desenvolvidas em cada uma das disciplinas científicas e, organicamente, pelo seu conjunto (MEC, 2006).

Pouco mais de vinte anos da ocorrência do trágico acidente com o radioisótopo do Césio-137 ( ${ }^{137} \mathrm{Cs}$ ), na cidade de Goiânia, Estado de Goiás - Brasil, ainda é preciso discutir suas possíveis contribuições históricas ao Ensino de Biologia e Química no Ensino Médio.

Como uma cápsula de Césio-137, utilizada para a inativação de câncer em seres humanos como fonte de emissão de raios gamas (COLLINS et al, 1988) pode ser abandonada em um hospital em ruínas? Omissão do poder público? Por quais razões o Fundo Estadual do Meio Ambiente de Goiás foi o mais bem indenizado se comparado às pessoas irradiadas? Questionou Borges (2007).

Questões como câncer induzido, mutações genéticas, inúmeras doenças decorrentes da exposição a fontes radioativas, reciclagem do lixo urbano, produção de energia elétrica a partir de fontes radioativas, acúmulo e destino do lixo radioativo provenientes destas. Todos são também temas recorrentes no Ensino de Química (FSE, 2007; MEC, 2007; 2006; 2002; MERÇON; QUADRAT, 2004; HELENE, 1996). Do mesmo modo, em Biologia é maior a possibilidade de ocorrer conexões entre Química e Física, já que temáticas destas áreas do conhecimento são aglutinadas em uma única área na Educação de Ensino Fundamental: Ciências (MEC, 2006).

Leite e Hoper (1988) preferem chamar o episódio de 13 de setembro de 1987 em Goiânia - Goiás de "incidente", pois a denominação acidente estaria dirigida aos trabalhadores de áreas de risco iminentes, por exemplo, empregados das Usinas Angra I e II, em Angra dos Reis, no Estado do Rio de Janeiro ou pesquisadores das Universidades Federais e mesmo profissionais que trabalham diretamente em locais de risco. Os autores ainda prosseguem, o que ocorreu em Goiânia foi uma sequencia de erros desde a abertura da cápsula até a atuação da equipe que atuou na descontaminação 
da área - para citar algumas, estavam sem uniformes adequados (compraram macacões em tecido e botas no comércio local) (LEITE; ROPER, 1988). O CNEN denomina o acidente por uma "[...] contaminação radioativa, isto é, existência de material radioativo em lugares onde não deveria estar presente" (CARDOSO, 2010b).

É relevante discutir com os alunos a questão e historicidade do primeiro acidente radioativo no Brasil em área urbana que envolveu questões de diferentes ordens para sua ocorrência, ganhou dimensões internacionais na mídia e alterou radicalmente o imaginário das pessoas sobre a ciência (OLIVEIRA, 2007). Temas como: o abandono inadequado ou descarte do lixo radioativo no hospital abandonado, o papel social desempenhado pelos catadores de lixo reciclável, as políticas públicas sobre a questão do destino do lixo, a questão da impunidade dos responsáveis envolvidos são pertinentes e relevantes até a presente data.

As primeiras cápsulas de Césio-137 ( $\left.{ }^{137} \mathrm{Cs}\right)$ chegaram ao Brasil, em 1950, importadas dos Estados Unidos da América (LEITE; ROPER, 1988). Os hospitais na época utilizavam comumente as cápsulas de Césio-137 $\left({ }^{137} \mathrm{Cs}\right)$ para o tratamento clínico do câncer, estas "[...] foram substituídas pelas de cobalto-60, que, entre outras razões técnicas, apresentam maior rendimento terapêutico" (CARDOSO, 2010).

A notícia em sua maior simplicidade era esta: dois catadores de papel recolheram uma bomba de Césio 137, abandonada num terreno baldio. Romperam seu invólucro de chumbo com golpes de marreta e descobriram uma cápsula fluorescente, altamente radioativa, que passou a circular na cidade como se fosse pedra preciosa, como se fosse um pedaço azul do céu, caído, subitamente no Bairro Popular para fazer a felicidade dos pobres do planeta (GABEIRA, 1987).

De outro modo, sem a poesia de Gabeira, o Greenpeace destaca:

O césio 137, subproduto das usinas nucleares obtido pela fusão do urânio 235, foi largamente empregado no tratamento de vítimas de câncer durante décadas, por meio da radioterapia. Em Goiânia, ele fora retirado de dentro de um equipamento que se encontrava nas ruínas do que costumava ser o Instituto Goiano de Radioterapia (IGO), no Centro da cidade. (GREENPEACE, 2010d).

O primeiro acidente radioativo no Brasil, ocorrido no ano seguinte ao de Chernobyl, atual Ucrânia, não ocorreu nos locais onde mais foi temido pela população, 
isto é, nas Usinas de Angras dos Reis no Rio de Janeiro ou nos laboratórios de pesquisa de aceleradores de partículas da USP em São Paulo:

O Centro de Aceleradores Ciclotron (CAC) iniciou suas atividades em meados da década de 70, com o nome de Divisão de Danos de Radiação. Nesta época, com a instalação do ciclotron CV-28 (The Cyclotron Corporation - USA), foram realizados os primeiros experimentos no IPEN para produção de radioisótopos (Gálio-67, Iodo-123, Tálio-201 e Índio-111) empregados em diversos diagnósticos por imagem na medicina nuclear. (IPEN, 2006)

O acidente de Goiânia gerou e ainda gera discussões éticas: "Deixem os mortos em paz”, lamenta morador de Goiânia, sobre a exploração pública da tragédia. É o que também escreve um escritor judeu sobre as inúmeras mortes ocorridas no holocausto da II Guerra Mundial. No último capítulo do livro, argumenta que refazer tal discussão é como se os matássemos uma segunda vez (WEISEL, 2003). O caso do acidente do Césio-137 em Goiânia - Goiás, além das inúmeras dicotomias decorrentes do fato: entre o bem e o mal, a ciência e a religião, abastados e miseráveis, inocentes e culpados; é um fato que transcende o espaço-tempo e as fronteiras de questões éticas, conhecimento científico e analfabetismo científico, relações CTSA e ainda do entendimento público de ciência.

Além dos mortos, feridos e contaminados pela radioatividade, a abertura da cápsula de chumbo por sucateiros e o descaso com os verdadeiros responsáveis deixou profundas marcas no imaginário de toda uma geração. Os assuntos públicos e éticos também ultrapassam os limites de Goiânia ou da pequena cidade de Abadia de Goiás que teve sua autonomia municipal reconhecida em troca do recebimento $\mathrm{e}$ armazenamento permanente de pouco mais de 13 toneladas de lixo radioativo geradas pelas $18 \mathrm{~g}$ de ${ }^{137} \mathrm{Cs}$ (OLIVEIRA, 2007).

Os acidentes nucleares ainda têm repercutido em pesquisas em todo o mundo que continuam na área das ciências aplicadas na contaminação de latossolos (WASSERMAN et al., 2002), na pesquisa de suas consequências ambientais no Ensino da Física Moderna (MEIGIKOS DOS ANJOS et al., 2000), pesquisas sobre o acúmulo de ${ }^{137}$ Cs em seres humanos em Chernobyl (TAKANO, 1996), acúmulo de ${ }^{137}$ Cs em duas espécies de cogumelos comestíveis coletados de 1987 à 1998 em vários países da Europa e Suécia (MASCANZONI, 2000), sobre a contaminação por ${ }^{137}$ Cs no solo de Abadia de Goiás - Goiás (MARUMO; SUAREZ, 1990), em obras do romance literário 
(PINTO, 1987; GABEIRA, 1987), filmes (PIRES, 1990) e documentários (ABIRACHED, 2007).

\section{A LINGUAGEM DE HISTÓRIAS EM QUADRINHOS COMO RECURSO DIDÁTICO}

Uma foto-charge em uma revista de grande circulação dizia assim, pouco antes do 'incidente' em Goiânia - Goiás, Brasil: “Aqui em Chernobyl está tudo bem!”. O maior acidente radioativo da história era traduzido com sadismo e sarcasmo no balão da fala inserido em uma imagem do personagem bizarro do Mestre Yoda, da série Star Wars, que teve início no final da década de 70, do diretor e escritor George Lucas. Este exemplo demonstra como as charges e cartoons têm em seu histórico traços de ranços ideológicos, preconceitos, humor negro, sarcasmo, mensagens políticas e noções de moral distorcidas que condenaram seu uso em ambiente escolar (VERGUEIRO; RAMOS, 2009; GONDIN et al., 2008).

Acerca do acidente em Chernobyl, o documento "365 razões para se opor a energia nuclear", do grupo ativista Greenpeace, relata que com o fim da II Guerra Mundial, após as duas bombas nucleares no Japão, a ocorrência de um acidente radioativo de grande porte era apenas uma questão de tempo. À $01 \mathrm{~h} 23 \mathrm{~m}$, de 26 de abril de 1986, ocorreu a explosão da Usina Nuclear de Chernobyl (Ucrânia), foi um preço caro que a Humanidade teve que pagar por escolher utilizar a energia nuclear (GREENPEACE, 2010e). O mesmo documento relata também o acidente de Goiânia.

As histórias em quadrinhos, cartuns e mangás têm sido recursos importantes para o ensino de Ciências, inclusive, Física, Química e Biologia (GOMES, 2009; PIZARRO, 2009; VERGUEIRO; RAMOS, 2009; BARBOSA et al, 2007; RABONI, 2005), entretanto, é preciso alertar sobre os critérios de utilização e disposição para a crítica que os docentes têm diante de histórias em quadrinhos (cartuns, mangás, etc.) produzidos pelos alunos, selecionados por eles ou mesmo pelo próprio docente. É importante fazer tal ressalva, já que muitos quadrinhos trazem erros conceituais graves em ciências; preconceitos éticos, étnicos, sociais e culturais; estereótipos; ironias; sarcasmo; ideologias; se faz necessário, segundo estes autores, ter uma perspectiva e análise crítica dos conteúdos, simbologia e temática tratados (PIZARRO, 2009; VERGUEIRO; RAMOS, 2009; KAMEL; LA ROCQUE; 2006).

Diante do quadro acima exposto, foram objetivos deste estudo: investigar se os alunos do ensino médio conheciam eventos sobre acidentes radioativos no Brasil e no 
mundo; propiciar aos alunos uma breve investigação sobre eventos que desencadearam o acidente radioativo Brasileiro que marcou a história do Brasil na década de 80; promover discussões que favorecessem a compreensão das causas e consequências do acidente com o radioisótopo de Césio-137; favorecer a ocorrência de discussões sobre: (a) o descaso político-social e o preconceito sofrido pelas vítimas do Césio-137; (b) o destino do lixo radioativo e consequências sócio-político-ambientais; (c) sintomas, manifestações e consequências às vitimas após a contaminação com o Césio-137; além de incentivar a confecção e exposição de cartazes para a divulgação no ambiente escolar sobre os 20 anos da ocorrência do acidente em Goiânia para demais turmas da escola.

\section{METODOLOGIA}

Na Pesquisa Qualitativa (DUARTE, 2002) os dados não são computados em números, mas estão organizados no decorrer das atividades produzidas, entrevistas, muitas vezes dissimulados em palavras ou ideias expressas no texto e, neste caso, também em histórias em quadrinhos. Segundo este autor, o direto contato do pesquisador com o campo e com os participantes da pesquisa poderia, a princípio, sugerir uma possível imparcialidade na análise dos dados. Por outro lado, tal aproximação facilita a apreensão dos significados atribuídos ou interpretações dadas pelos sujeitos participantes aos fenômenos investigados.

Participaram deste estudo aproximadamente 60 (sessenta) alunos provenientes de quatro turmas de 2. ${ }^{\circ}$ anos do Ensino Médio e o professor da disciplina Química. As aulas ocorreram numa escola pública estadual, no período noturno, com 15 alunos em média por sala de aula, localizada na região central de uma cidade de médio porte do interior de São Paulo. Os alunos foram convidados pelo professor a participar de uma 'investigação' que durou aproximadamente quatro semanas - 8 (oito) horas/aulas sobre as origens do primeiro acidente radioativo ocorrido em Goiânia em 1987 e suas origens. As aulas da disciplina Química ocorreram em duas horas-aulas semanais com quarenta e cinco minutos. Pesquisador e professor adotaram a utilização da metodologia do Ensino por Investigação (CAMPOS; NIGRO, 1999) na qual os alunos deveriam buscar informações, organizar dados coletados, estabelecer relações e formular hipóteses (PAVÃO, 2008; MEC, 2006; 2002).

A produção e organização de história em quadrinhos (VERGUEIRO, 2004), cartazes e textos poderiam compor uma importante fonte de material didático para 
explorar concepções alternativas dos alunos, além de avaliar as aprendizagens e explorar as manifestações sobre os conceitos em Química.

As propostas aqui adotadas pressupõem a elaboração de um material didático (cartazes) que fizeram parte de uma exposição. Vergueiro (2004) defende a possibilidade de elaboração de metodologias de trabalho docente [mesmo em química] que apresentem oportunidades de uso do recurso das histórias em quadrinhos como ferramenta para a compreensão dos conteúdos de aprendizagem. O planejamento destas estratégias de ensino evidenciaria oportunidades de apreensão de conteúdos de modo atrativo e de produções de atividades que já fazem parte rol de repertórios dos alunos em outras disciplinas.

\section{PROCEDIMENTOS DE COLETA DE DADOS}

O procedimento de coleta de dados foi estruturado e organizados em três Etapas distintas descritas, sinteticamente, abaixo:

Etapa 1 - Discussão sobre buscas bibliográficas em livros e sites da internet: os alunos, organizados em equipes de três integrantes, e sob orientação do professor de Química, localizaram e selecionaram diferentes textos provenientes de diferentes links da internet e/ou livros didáticos sobre o tema. A adequação destes textos foi verificada pelo docente para cada uma das equipes. Estes foram impressos, lidos e discutidos entre cada um dos grupos de alunos e, em seguida, socializados - isto é, apresentado oralmente - aos demais alunos da sala. De outro modo, cada grupo apresentou aos demais as principais ideias de cada texto que buscaram na internet.

Etapa 2 - Sensibilização - música e videoteipe: em seguida, depois de sintetizar em seus cadernos as ideias centrais de cada texto, os alunos ouviram as músicas-tema de um documentários que veriam a seguir. Elas eram: 'Radioactivity' (KRAFTWERK, 1975) e 'Pie Jesu' (WEBBER, 1985). Depois disso, assistiram e, em seguida, a um documentário temático exibido pela Rede Globo de Televisão: 'Programa Linha Direta Justiça: Césio-137', (ABIRACHED, 2007). Os alunos, nas aulas subsequentes, discutiram sobre suas leituras e sobre o vídeo acerca do episódio do Césio-137 em Goiânia.

Etapa 3 - Produção de cartazes, divulgação à comunidade escolar dos trabalhos e o filme de Roberto Pires: os alunos foram convidados, como encerramento da Unidade Didática, a duas atividades: (1) confecção de cartazes - com estilo livre (isto é, colagens, desenhos, materiais diversos, etc.) e a realização de uma exposição de 
cartazes - 'Acidente Radioativo do Césio-137 em Goiânia - 20 anos (1987-2007)' objetivando a divulgação do acidente radioativo ocorrido entre seus pares da unidade escolar - (desde o $6 .^{\circ}$ ano ao último ano do Ensino Médio) e; (2) assistir ao premiado filme: 'Césio, o Pesadelo de Goiânia' (PIRES, 1990).

\section{ANÁLISE DOS RESULTADOS}

$\mathrm{Na}$ Etapa 1, o professor iniciou as aulas dialogando com os alunos sobre o assunto radioatividade. Fez questionamentos e, diante das negativas dos alunos, verificou que os alunos nada ou muito pouco conheciam sobre esta temática. O professor desenhou o símbolo da radioatividade na lousa e, depois disso, questionou novamente os alunos. Alguns disseram que já haviam visto e qual era o significado - " $E$ o símbolo da radioatividade”. Questionados onde haviam visto os símbolos, alguns viram em desenhos animados (por exemplo, Os Simpsons; Johnny Test; As Terríveis Aventuras de Billy e Mandy; Meninas Super-poderosas, entre outros). De fato, alguns destes desenhos exibem com frequência o símbolo em alguns episódios, especialmente, com maior frequência o desenho animado Johnny Test (Figuras 1 e 2), do Cartoon Network (e Rede Record, TV aberta no Brasil), que a cada mudança de diálogo no desenho, apresenta o símbolo da radioatividade.

Os alunos relataram sobre a aquisição de superpoderes, forças sobre-humanas, deformações, aumento de tamanho, depois do contato dos personagens dos desenhos com a radioatividade. Eles também se lembraram do tratamento do câncer, mencionando a radioterapia.

\section{Figura 1: logo piloto}

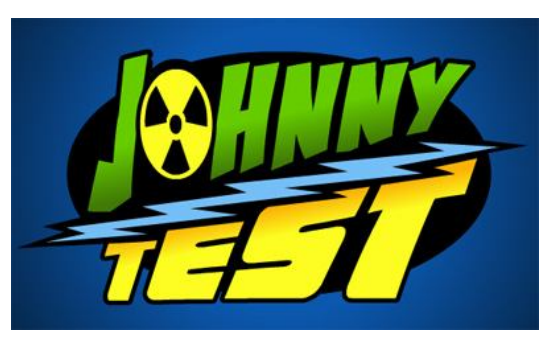

Fonte: em web

$<$ http://th00.deviantart.net/fs70/300W/i/2010/343/f/0/review_johnny_test_by_wormtail96-d34j715.jpg > 
Figura 2: logo atual

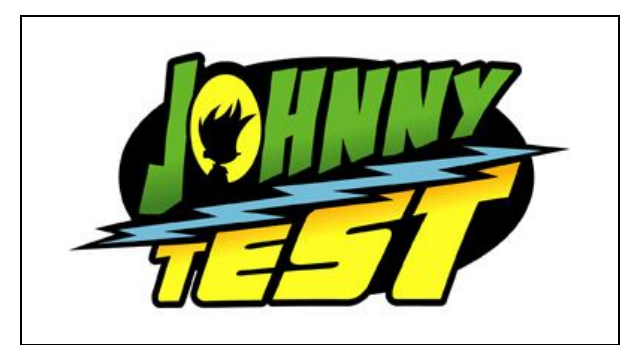

Fonte: em web $<$ http://upload.wikimedia.org/wikipedia/en/d/d5/Johnny_Test_Logo.jpg >

Depois das discussões iniciais, os alunos foram à sala de informática buscaram textos na internet sob as palavras-chaves fornecidas previamente pelo professor: "radioatividade"; "acidentes radioativos"; "Chernobyl"; "Césio-137 Goiânia". Os alunos encontraram diferentes materiais em diferentes links da internet que passaram pelo critério de adequação do professor da disciplina, isto é, em relação às linguagens dos textos e à compreensão dos alunos diante da complexidade dos diversos materiais encontrados.

Muitos destes textos traziam informações sobre: o acidente em Chernobyl; II Guerra Mundial e as bombas no Japão; acidente do Césio em Goiânia; sobre o acidente em Three-Mile Island, entre inúmeros outros. Os alunos realizaram buscas em livros didáticos presentes na biblioteca da escola. $\mathrm{O}$ foco dos textos foi novamente denotado pelo professor que seria o acidente radioativo em Goiânia - Goiás. Entretanto, o professor permitiu que alguns dos grupos, em cada uma das salas, fizessem a leitura de textos sobre o acidente em Chernobyl - diante da solicitação de alguns alunos. Isto evidenciou aspectos positivos durante a discussão dos alunos ao estabelecer relações entre o acidente em Goiânia e nos demais locais do mundo.

Depois de impresso os textos, os alunos realizaram leituras em grupos de três alunos, em média. Apresentaram, por escrito em seu caderno de anotações e, depois oralmente, aos demais alunos uma síntese do material lido. Vale ressaltar que o professor revisou alguns conceitos, em aulas expositivas, que considerou importante antes de avançar sobre a temática radioatividade. Estes conceitos versaram sobre fusão e fissão nuclear, emissão de partículas do núcleo atômico, núcleos instáveis/radioativos, isotopia, entre outros. 
Na Etapa 2, os alunos foram convidados a fazer uma atividade na qual eles ouviriam as músicas previstas e, registrariam em seguida, quais ideias ou impressões viriam à cabeça. Os alunos relatariam seus sentimentos. Esta atividade não foi bem recebida pelos alunos do Ensino Médio, argumentaram que não havia a necessidade de 'fechar os olhos', que isso era 'estranho'. Ficou a critério dos alunos como eles iriam ficar - de olhos abertos ou não. Com a primeira música, os alunos registraram que se tratava de uma musica 'tecno', que lembrava a euforia de festas 'raves' e boates - a do grupo Kraftwerk (do alemão, usina de energia). Na segunda música, Pie Jesu, os alunos disseram que lembrava uma oração ou que trazia uma sensação de tristeza ou angústia. Os alunos foram alertados para ver como estas duas músicas foram dispostas no vídeo que assistiriam em seguida.

Depois de assistir ao documentário: 'Linha Direta Justiça - Césio 137', os alunos discutiram em grupos e depois com todos os demais colegas e o professor. Das análises, os alunos argumentaram que a música inicial e as imagens (azuis em sua maioria) da abertura do programa eram mesmo para "seduzir o público para o programa", "chamar a atenção do telespectador sobre algo novo". A música final, segundo os alunos, dava mesmo "a impressão de uma oração aos mortos em Goiânia"; "sobre angústia, dor e sofrimento". Associaram esta música ao apedrejamento do caixão no enterro da menina Leide.

Depois de assistir ao documentário, surgiram perguntas dos alunos como estas: "Professor, como eles não sabiam que aquilo era um material radiativo?" E o professor respondeu com outra pergunta. "Vocês saberiam? Coloquem-se na condição dos catadores de lixo recicláveis. Vocês saberiam?” (insistiu o professor). Os alunos retrucaram: "Como deixaram para trás algo tão importante como uma cápsula radioativa?"; "Quem foram os responsáveis? Eles foram punidos? O que a justiça fez?" A seguir, serão apresentados alguns trechos dos diálogos:

(Aluno A) - "Professor, como algo que é utilizado para tratar doenças como o câncer pode fazer mal à saúde? Pode causar câncer e outras doenças? Essa cápsula de Césio-137 estava em um hospital, não?"

(Professor P1) - "Não sei se o exemplo vai ajudar ou atrapalhar, mas vamos lá... Pensem assim: a eletricidade, se utilizada de forma controlada, pode ser muito útil no nosso dia-a-dia. Ela pode até salvar vidas em hospitais, certo?"

(Aluno B) - "O que a eletricidade tem a ver?" (risos)

(P1) - "Calma aí, pessoal, é só um exemplo. Imaginem-se levando um leve choque elétrico. À medida que a voltagem é aumentada, os danos vão ser bem maiores ao organismo. A exposição controlada à radioatividade, em hospitais, pode fazer com que células cancerosas parem de se multiplicar - este é o objetivo da radioterapia. A exposição contínua e descontrolada à radiação pode fazer com que apareçam 
todos os sintomas que vocês viram no vídeo e nos textos - queda do sistema imunológico, queda dos cabelos e dentes, indução ao câncer e inúmeros outros tipos de doenças".

(Aluno A) - "Como puderam esquecer algo como esta cápsula para trás? Fizeram a mudança de prédio e abandonaram a cápsula de Césio?"

(P1) - "Isso mesmo. E fizeram isso sem calcular o estrago que poderia ocorrer.[...] Muitos de vocês já fizeram radioagrafias, não?"

Alunos - "Hã?"

(P1) - "Já tiraram um raio-X ou viram um chapa mostrando ossos do corpo humano ou dentes no consultório dentário - como aquelas aqueles raios-X panorâmicos para aqueles que utilizam aparelhos nos dentes?"

(Alunos) - "Ah, isso sim." "Já fiz quando quebrei o braço..." "Eu fiz no ortodontista."

(P1) - "Um raio-X demora uma fração de segundos, mas vocês repararam se o técnico responsável, o que faz o raio-X permanece na sala todo o tempo?"

(Aluno A) - "É verdade. Quando fiz os raios-X, o técnico sempre ficou em outra salinha dizendo que não é para se mexer..."

(P1) - "Alguém sabe dizer o motivo?"

(Aluno B) - "Para não ficar o tempo todo em contato com a radiação?"

(P1) - "Isso mesmo, B. Imaginem quantas radiografias ele faz em um dia, em um mês, no decorrer de um ano ou de dez anos... Possivelmente já teria desenvolvido alguma doença”".

(Aluno B) - "Ah, então é por isso que eles [os técnicos] saem..."

A analogia da eletricidade utilizada pelo professor pode não ter surtido o efeito esperado acerca do que os alunos compreenderam dos efeitos dos materiais radioativos no corpo humano.

Na Etapa 3, os alunos produziram, em equipes, cartazes sobre o acidente em Goiânia e fizeram uma exposição na escola (apresentadas nas figuras 4 à 11 seguintes). As imagens, a seguir, apresentam alguns destes trabalhos e o cenário da exposição (note que os alunos escolheram o local próximo ao oratório). As figuras abaixo apresentam alguns destes trabalhos: 
Figura 3: produções dos alunos

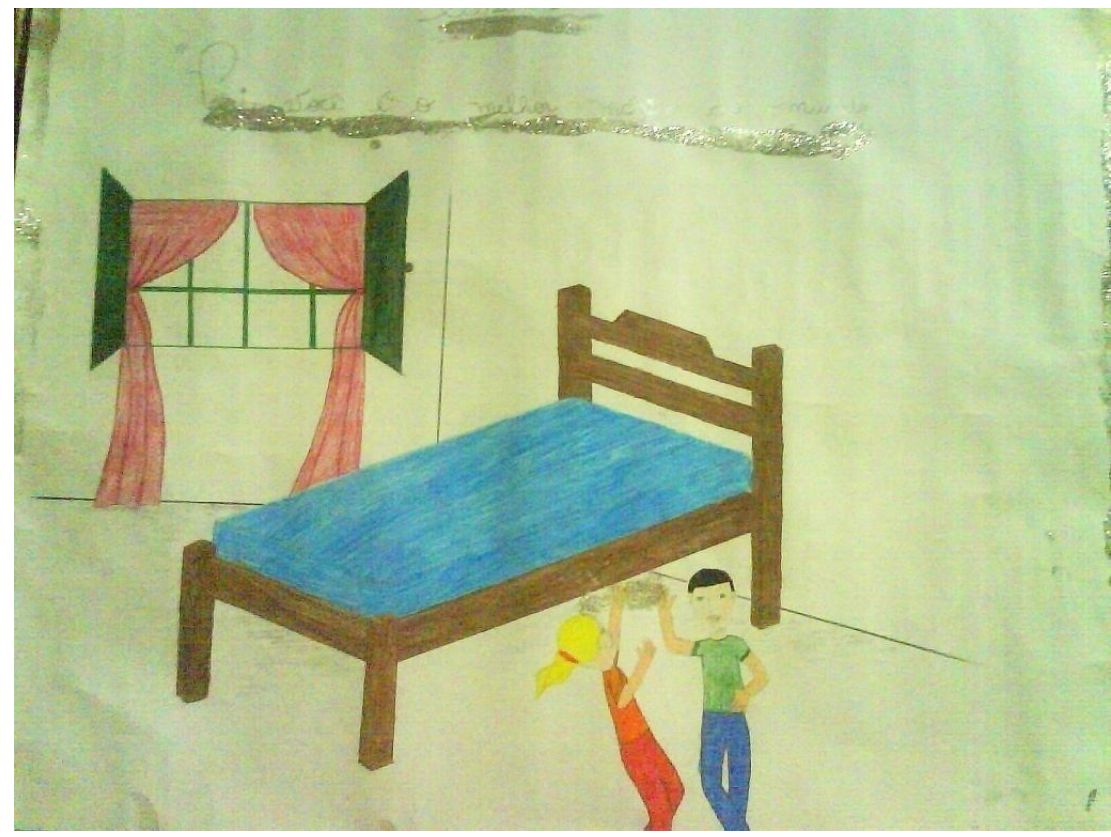

Legenda: No cartaz explora a imagem da menina Leide (primeira vítima do Césio-137) contemplando o brilho do césio embaixo de sua cama e exclamando: " - Pai, você é o melhor mágico do mundo". Fonte: autores.

Figura 4: produções dos alunos

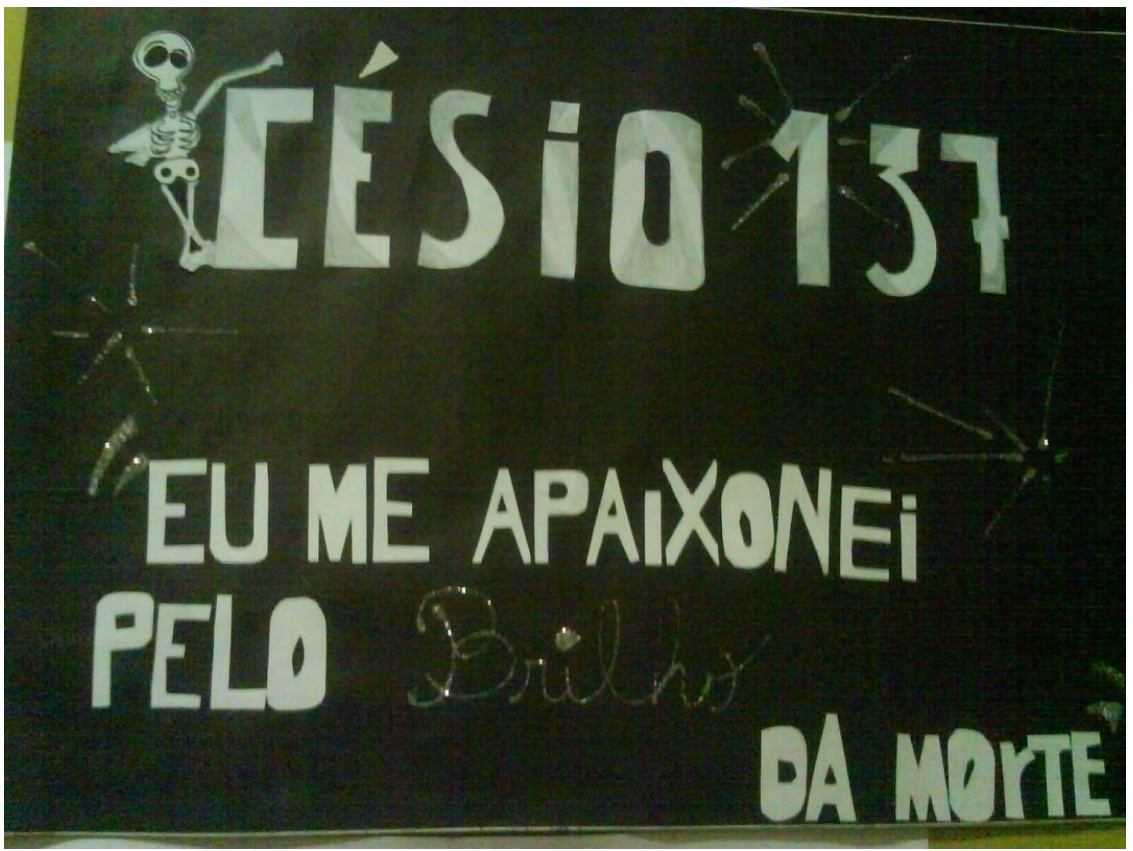


Legenda: “Césio - 137: 'Eu me apaixonei pelo brilho da morte”. Há certo humor negro ou sarcasmo com a exposição da imagem do esqueleto recostado sobre a palavra Césio-137 e uso do brilho da cola gliter na palavra "brilho" e na representação de partículas radioativas. Fonte: autores.

Figura 5: produções dos alunos

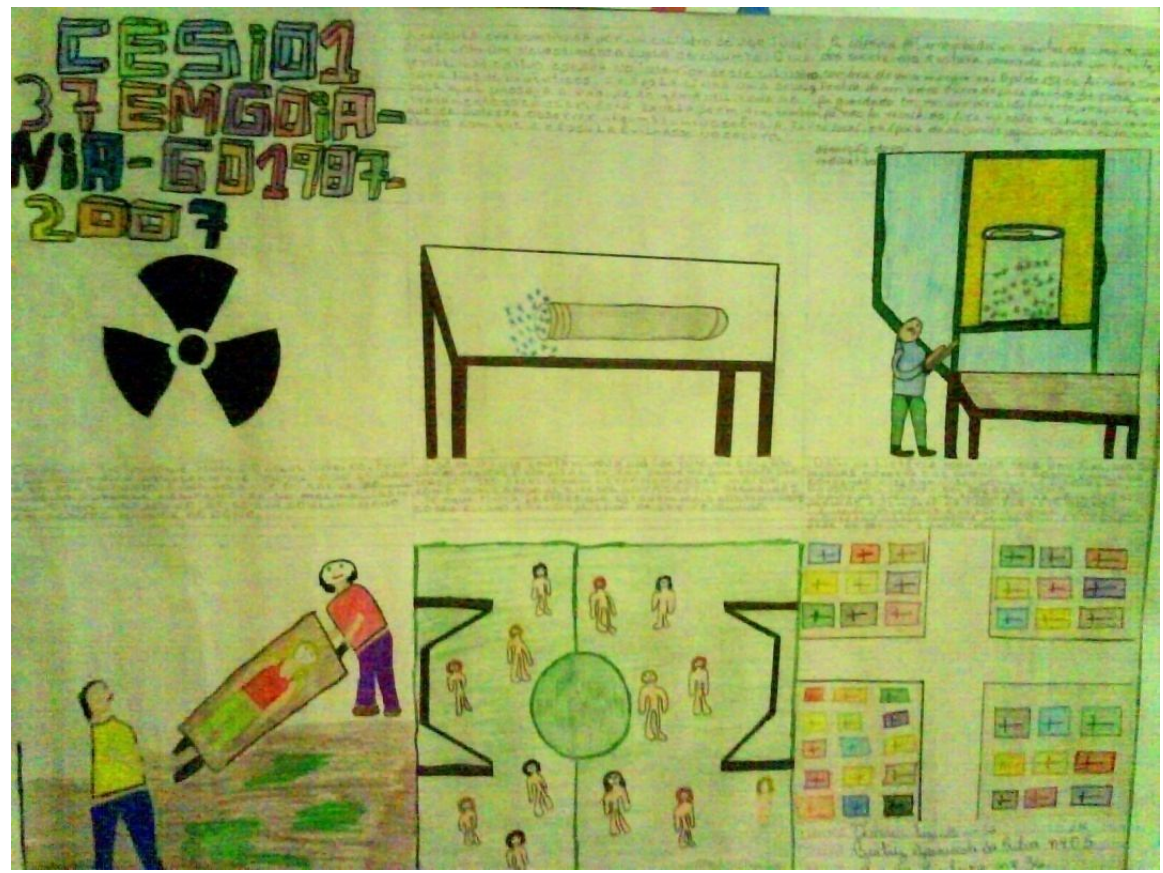

Legenda: No Cartaz “Césio-137 em Goiânia - Goiás (1987-2007) fez uso das imagens para descrever em sequencia os eventos ocorridos em 1987. Apresentou: (1) o símbolo da radioatividade; (2) a abertura da cápsula de césio no hospital; (3) Os técnicos da CNEM medindo a radiação; (4) O enterro das vítimas do césio; (5) o agrupamento de pessoas contaminadas/expostas à radiação no campo de futebol; (6) $O$ cemitério e a descrição do apedrejamento do caixão de Leide das Neves Ferreira". Fonte: autores. 
Figura 6: produções dos alunos

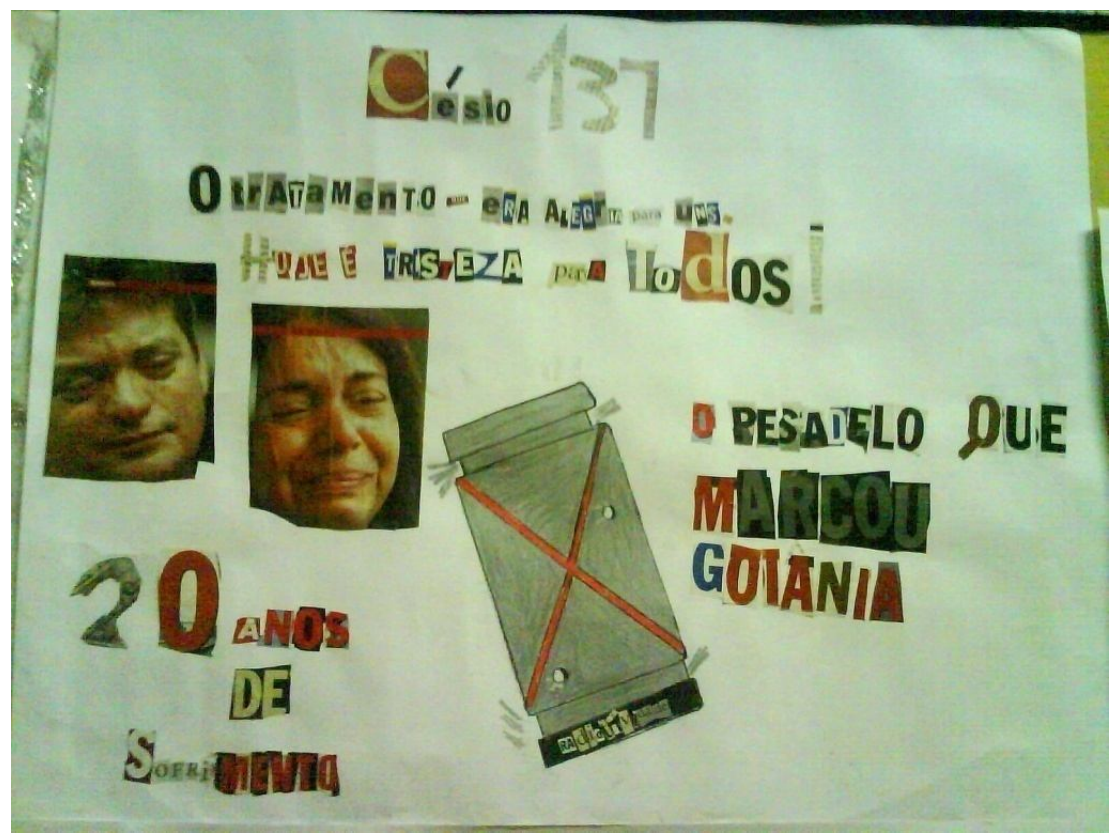

Legenda: $O$ trabalho explorou colagens de imagens de revistas e letras "Césio-137: o tratamento que era a alegria de uns. Hoje é tristeza para todos! O pesadelo que marcou Goiânia. 20 anos de sofrimento". No detalhe no centro do cartaz, apresentou-se a cápsula de césio com a inscrição radioatividade. Fonte: autores.

Figura 7: produções dos alunos

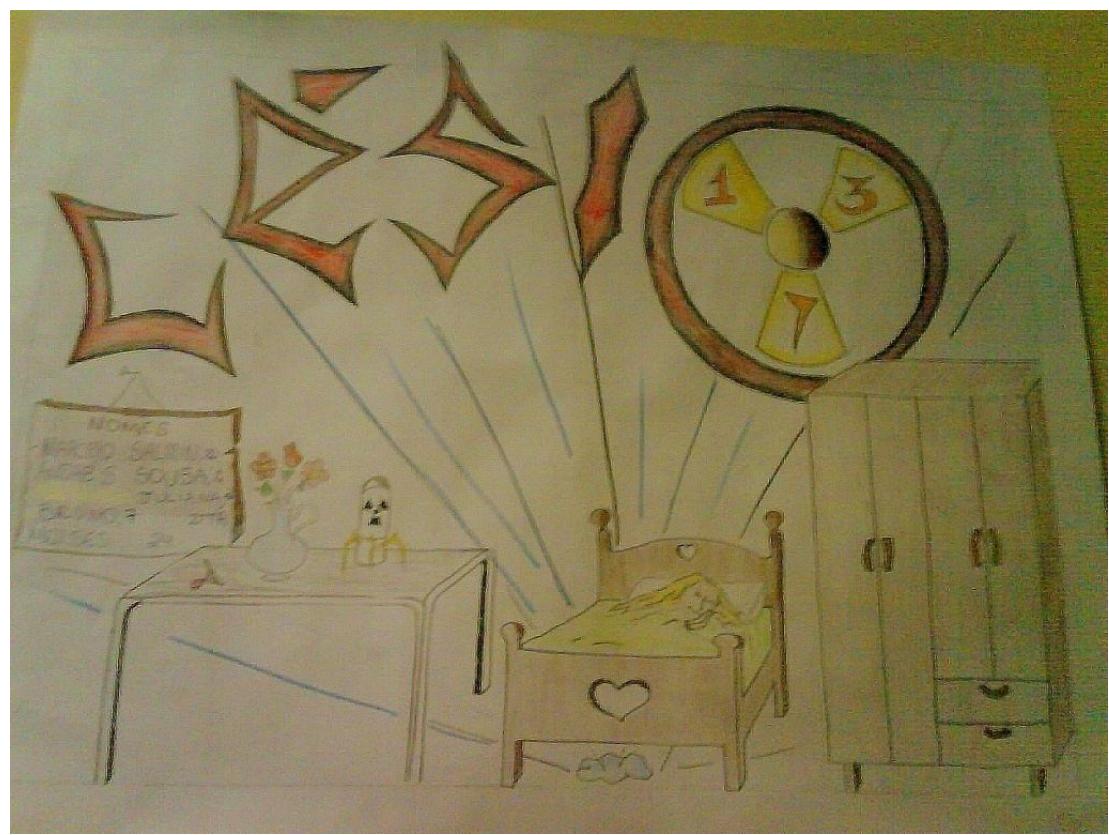

Legenda: O trabalho apresentou o quarto da menina Leide com as inscrições "Césio-137" refletidas a partir do brilho do pó de Césio-137 embaixo da cama da garota dormindo. Detalhe 
para a cápsula de Césio-137 sob uma mesa na lateral da cama e o guarda-roupa evidenciando o ambiente. Fonte: autores.

Figura 8: produções dos alunos

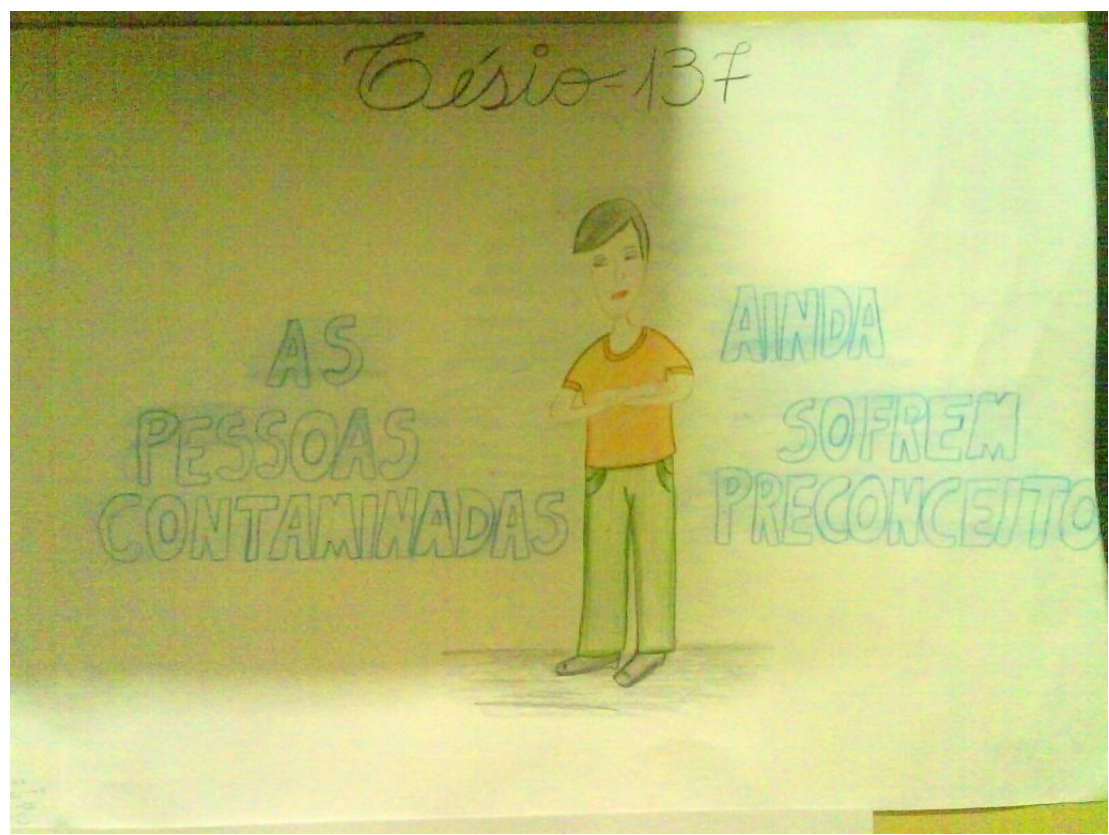

Legenda: $O$ cartaz do quadro deixa a seguinte mensagem "Césio-137 - As pessoas contaminadas ainda sofrem preconceito". A imagem representada é de um rapaz com uma expressão de tristeza e com os braços cruzados. Fonte: autores.

Figura 9: produções dos alunos

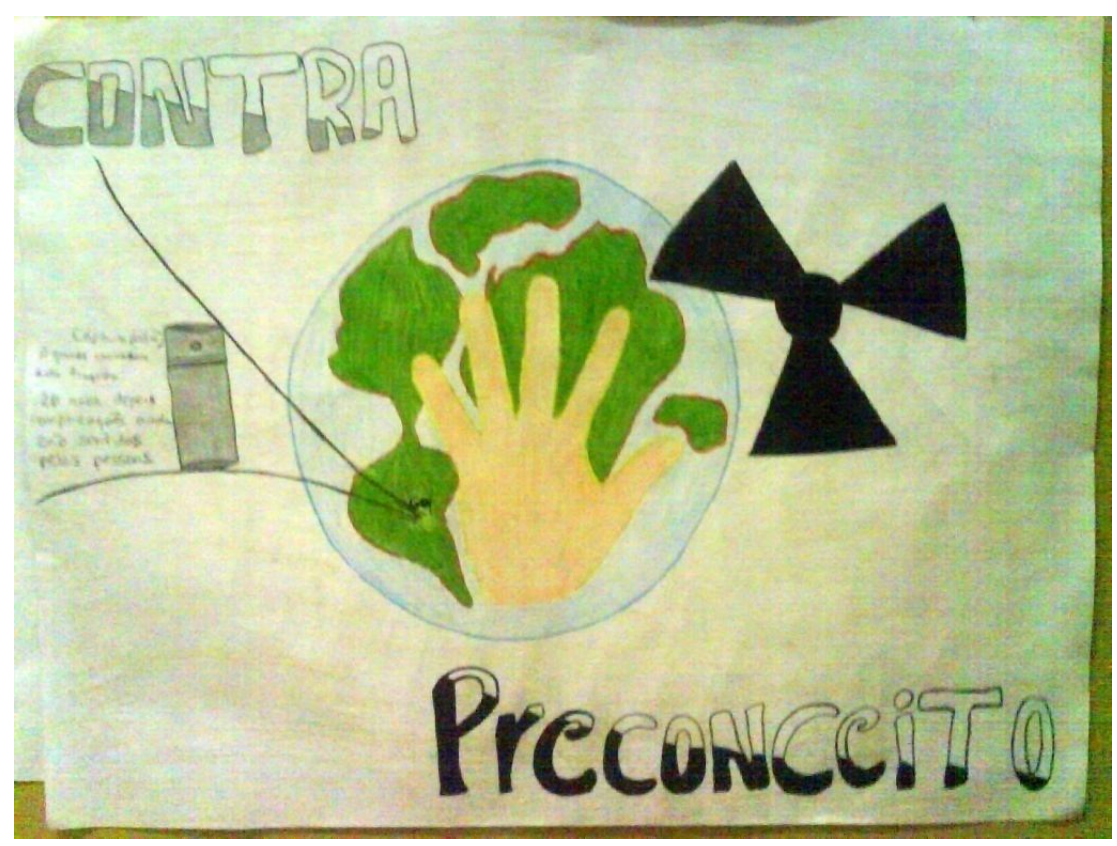




\section{Legenda: Uma mão simboliza o não ao preconceito contra os irradiados pelo Césio-137. Fonte:} autores.

Figura 10: produções dos alunos

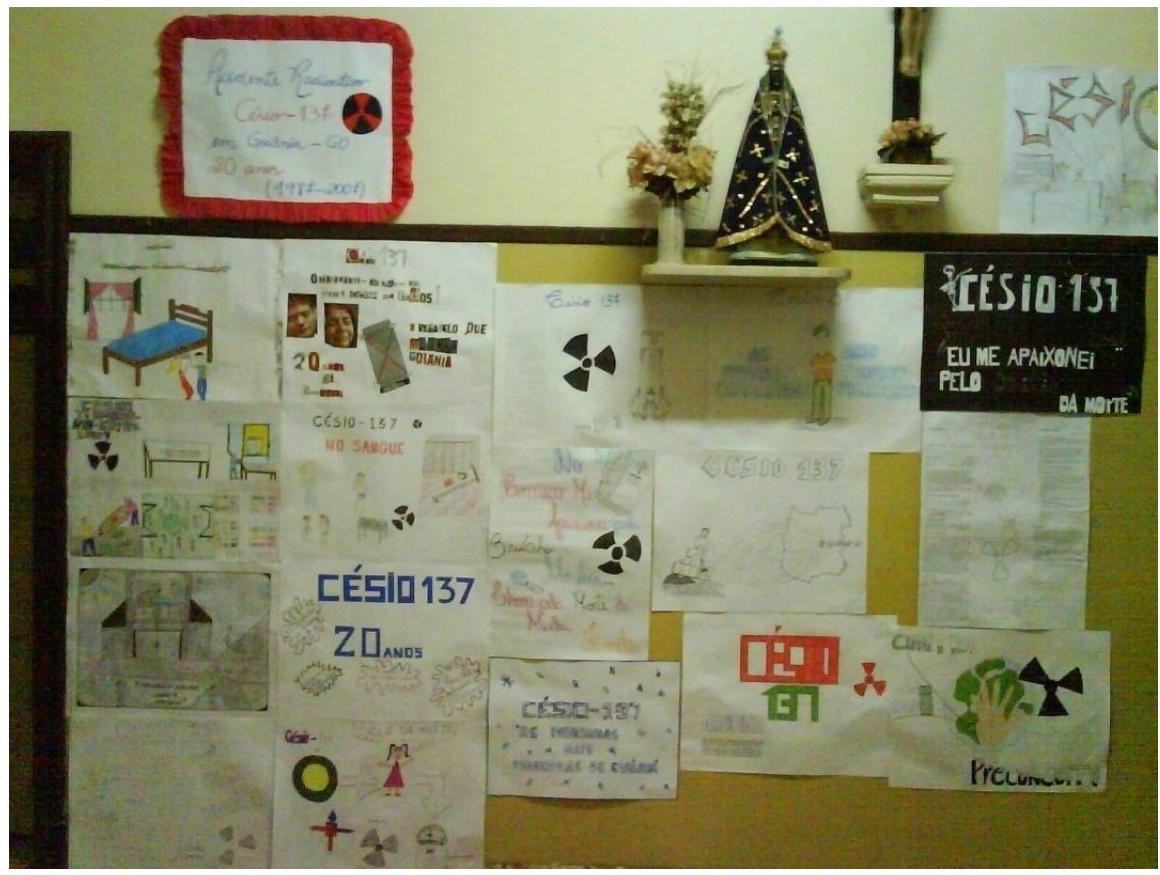

Legenda: Cenário dos trabalhos. Fonte: autores.

Os trabalhos acima apresentaram algumas das principais temáticas adotadas pelos alunos nos grupos durante a produção dos cartazes para a exposição. O professor havia alertado os alunos que não poderiam utilizar uma linguagem técnica da química, mas que poderiam explorar imagens e informações para que pudessem ser vista por toda a comunidade escolar.

As considerações dos alunos nas discussões durante as aulas e produção dos cartazes versaram principalmente sobre: (a) aspectos sociais (preconceitos em relação às vítimas); (b) educação ambiental (sobre os resíduos radioativos lançados no ambiente, saúde das pessoas e o tempo de meia-vida do Césio-137); (c) descaso da justiça pública e políticas governamentais em relação às vítimas da radiação; (d) apedrejamento do caixão no enterro da criança Leide (primeira vítima) e, sobretudo, (e) sobre o desconhecimento dos envolvidos - catadores de lixo reciclável - acerca da cápsula de césio. 
O grande temor demonstrado nos relatos dos alunos foi sobre o despreparo dos médicos em não reconhecer os sintomas, nas vítimas do Césio-137, da contaminação por radiação. Os alunos ressaltaram sobre despreparo dos Governos Federal e Estadual para lidar com a situação, pois localizaram matérias jornais sobre a contratação de trabalhadores braçais para a remoção das mais de 13 toneladas de lixo radioativo, sobre a farsa que sobressaiu na imprensa, o papel da imprensa acerca da discriminação das vítimas do Césio e da situação que permanece sem solução até os dias de hoje.

\section{CONSIDERAÇÕES FINAIS}

É notório que também histórias em quadrinhos, como toda mercadoria, passam por um processo de produção, há uma demanda, tem um público-alvo e, o mais importante, visa o lucro. Este trabalho não teve o objetivo de introduzir estas histórias em quadrinhos no ensino de química para que fossem analisadas. A proposta aqui foi produzir cartazes que reproduzissem o que foi mais foi importante para os alunos durante a unidade didática, de modo, que outros alunos (públicos de outras faixas etárias) pudessem compreender. Foi intuito neste sentido, a produção de um material inteligível por alunos dos $6 .^{\circ}$ ao $9 .^{\circ}$ anos do Ensino Fundamental e pelas séries do Ensino Médio sobre a temática. Não teve como proposta, a exemplo do que propõem Vergueiro e Ramos (2009), inserir os cartoons 'de fora para dentro do ambiente escolar', para depois serem analisados. Entretanto, esta também é uma proposta válida para estudos futuros (PIZARRO, 2009; VERGUEIRO et al, 2004; KAMEL; LA ROCQUE, 2006) dada a vasta produção, não sobre o césio-137, mas sobre a radioatividade e os acidentes radioativos de modo geral.

Uma alternativa foi a proposta do pesquisador Raboni (2002) na qual o próprio pesquisador produziu histórias em quadrinhos para trabalhar com a formação de professores também se tornou um excelente recurso instrucional. Histórias como as produzidas por este autor não tem cunho comercial - nem poderia fora do contexto educacional (já que não satiriza ou ironiza os temas), mas que atende o compromisso com a ciência, já que dificilmente produzirá erros conceituais ou induzirá o leitor a erro.

As histórias em quadrinhos com finalidade comercial, especificamente sobre o césio-137 em Goiânia, são sobre o encantamento dos irradiados pelo brilho azul celeste do Césio-137, a deformidade causada pelas doenças, "o fim dos tempos" temido pela era nuclear, tudo isto foi motivo de sátira em cartoons produzidos e mesmo em desenhos na TV. Tanto que Gondin et al. (2008) apontam que... 
[...] o que é mais consensual é que essas produções humorísticas relacionadas ao acidente radioativo de Goiânia são específicas do humor na modernidade, uma época que ri de tudo, inclusive de suas catástrofes. As do primeiro grupo são mais ingênuas, mais contidas, mais solidárias; as do segundo, são irônicas, irreverentes e insensíveis. Mas os dois tipos devem ser consideradas - pelos historiadores culturais - narrativas que ajudam a construir um novo olhar sobre o acidente ocorrido em Goiânia. Seja como for, o riso provocado pelo acidente radiológico é uma riso amarelo. Ou seria um riso azul? (GONDIN et al, 2008).

Entretanto, este deslumbramento com os elementos radioativos não ficou restrito aos moradores de Goiânia, que mostraram o pó do cloreto de Cs-137 aos filhos e vizinhos, deram aos filhos. Este ofuscamento e encantamento pelo brilho dos elementos radioativos também atingiu grandes cientistas Pierre e Marie Curie. Era comum na época Pierre andar com uma amostra de rádio $(\mathrm{Ra})$ no bolso do colete para mostrar aos amigos. Por sua vez, Marie Curie também mantinha sal de rádio em sua cama, pois brilhavam no escuro. Mesmo na festa em homenagem ao doutoramento de Marie, o brilho de elementos radioativos foi exibido aos convidados como se fosse algo 'mágico ou surreal'. Todos os documentos produzidos que o casal Curie deixou para trás contém traços de radioatividade (FRÖMAN, 1996). Segundo a mesma autora, se qualquer pessoa for consultar estes documentos na Bibliothèque Nationale deve assinar uma declaração assumindo os próprios riscos, já que o 'tempo de meia-vida' do elemento rádio é de 1620 anos.

Em linhas gerais, os objetivos principais deste trabalho foram promover discussões que favorecessem a compreensão das causas e consequências do acidente com o Césio-137 em Goiânia. Além de favorecer a ocorrência de discussões com alunos do Ensino Médio e denotar os aspectos como o descaso político-social e o preconceito ainda sofrido pelas já envelhecidas vítimas do Césio-137; além de outros como o destino do lixo radioativo e consequências sócio-político-ambientais, instalações de novas usinas nucleares dentro dos planos de metas energéticas para o Brasil até 2030 (MEC, 2007, p. 31).

"Os Brasileiros ainda são tratados como gente menos gente" indignada relatou uma das alunas sobre o descaso com as vítimas. A indenização foi, em sua maior parte, para uma agência ambiental governamental (BORGES, 2007). Completou a aluna ainda: "Como que o governo pode indenizar o próprio governo"? Os alunos 
demonstraram grande indignação com relatos sobre o descaso com o lixo nuclear (que ficou por 10 anos em um aterro a céu aberto) e com a condição dos radioacidentados e o desenvolvimento de inúmeras doenças após o acidente em Goiânia. Silva (2007) aponta que as comemorações de aniversário geralmente remetem a superação de traumas e celebrações de ocasiões especiais. Infelizmente, completa a autora, não há nada a ser comemorado, pois há muita desinformação e preconceito em relação às vítimas, aos moradores e aos produtos da cidade. Feridas que o tempo não apagará facilmente.

Os alunos tiveram a oportunidade de analisar o vídeo apresentado (ABIRACHED, 2007) e dialogar sobre o uso da imagem e das músicas durante a exibição da matéria, a dramatização e mesmo o depoimento das vítimas. Apesar do curto espaço de tempo para desenvolver trabalhos em sala de aula como este em aulas de química, mesmo no ensino noturno, uma das alunas participantes disse ao professor da disciplina ao final das aulas: "Que bom que foram estas aulas! Por que você não trabalha sempre assim?”

Incentivar e proporcionar aos alunos que compreendam e melhor interpretem a natureza a sua volta é um princípio básico na Educação em Química (MEC, 2002; 2006). A Educação Química - e mesmo o conceito de Educação Ambiental - deve iniciar em casa, com os pais, continuar paralelamente no ambiente escolar e seguir por toda a vida dos indivíduos. Esta compreensão de cidadania certamente ultrapassa os limites dos muros escolares para a vida, na formação da cidadania e respeito para com o próximo.

O acidente com o Césio-137 ( $\left.{ }^{137} \mathrm{Cs}\right)$ em Goiânia não é apenas uma ferida aberta aos moradores da cidade de Goiânia, mas a todos que se omitem na Educação em CTSA. Afinal, a cidade de Goiânia é segura? Os seus problemas estão todos enterrados na cidade de Abadia de Goiás, nos mortos e numa população envelhecida de doentes que foram expostos ao Césio-137?

\section{REFERÊNCIAS BIBLIOGRÁFICAS}

ABEN. Associação brasileira de energia nuclear. Disponível em: < http://www.aben.com.br > Acesso: 20.11.2010.

ABIRACHED, M. (2007). Linha direta justiça: césio 137. [Filme-vídeo]. Central Globo de Jornalismo - Central Globo de Produção. Direção Geral de Milton Abirached, Rio de Janeiro - RJ, Rede Globo de Televisão - TV aberta pública, exibição em 09/ago/2007. DVD/-RW, 38 min. color. som. 
BBC NEWS. China executes two over tainted milk powder scandal: China has executed two people for their role in a scandal involving tainted milk powder that resulted in six children dying, officials have said, BBC News, 2009. Disponível em: < http://news.bbc.co.uk/2/hi/asia-pacific/8375638.stm > Acesso em 24.11.2009

BAIRD, C. Química ambiental. 2. Edição, Porto Alegre: Bookman, 2002.

BARBOSA, A.; RAMOS, P.; VILELA, T. Como usar as histórias em quadrinhos em sala de aula. Em: RAMA, A.; VERGUEIRO, W. (Orgs.), Coleção como usar na sala de aula, 3. ${ }^{a}$ Ed., São Paulo: Contexto, 2007.

BATISTA, I.R.S.; NASCIMENTO, M.G.B. O acidente com o césio 137 sob o olhar dos trabalhadores de vigilância sanitária. Em: Revista Universidade Federal de Goiás (UFG) - Dossiê Césio 137. Ano IX. N. ${ }^{\circ}$ 1, 2007. Disponível em: < http://www.proec.ufg.br/revista_ufg/agosto2007/textos/dossieGoianiaAcidente137.pdf $>$. Acesso em 18.03.2014.

BELTRAN, N.O.; CISCATO, C.A.M. Química coleção magistério 2. ' grau - série formação geral, São Paulo: Cortez, 2003.

BORGES, W. Perguntas sem respostas. Revista Universidade Federal de Goiás (UFG) - dossiê césio 137. 9, 1, 2007. Disponível em: < http://www.proec.ufg.br/revista_ufg/agosto2007/textos/perguntassemrespostas.pdf $>$ Acesso em: 01.02.2014.

BRÜCKMANN, M. E.; FRIES, S. G. Radioatividade. Porto Alegre: Instituto de Física - UFRGS, 1991.

CAMPOS, M.C.C.; NIGRO, R.G. Didática das ciências: o ensino-aprendizagem como investigação. São Paulo: FTD, 1999.

CARDOSO, E. M. (Org) Aplicações da energia nuclear. Em: Comissão nacional de energia nuclear, 2010a, Disponível em: < http://www.cnen.gov.br> Acesso: 12.12.2013.

CARDOSO, E. M. Apostila educativa: radioatividade. Comissão nacional de energia nuclear, 2010b. Disponível em: 〈http://www.cnen.gov.br/ensino/apostilas/radio.pdf > Acesso em 09.07.2013.

CHAVES, E.G. (2007). Goiânia é azul: o acidente com o césio 137. Revista Universidade Federal de Goiás (UFG) - dossiê césio 137. Disponível em: 〈http://www.proec.ufg.br/revista_ufg/agosto2007/textos/dossieGoianiaAzul.pdf > Acesso em: 05/01/2014.

CURIE, M.S. Les rayons de Becquerel et le polonium. Révue Générale des Sciences, 10, 41-50, 1899.

DAMASIO, F.; CALLONI, G. Perdendo o medo da radioatividade: pelo menos o medo de entendê-la. 2007. Disponível em:

<http://ararangua.cefetsc.edu.br/ciencias/radioatividade.pdf $>$ Acesso em: 02/02/2014. 
DUARTE, R. Pesquisa qualitativa: reflexões sobre o trabalho de campo. Cadernos de Pesquisa, 15, 1, 139-154, 2002.

FELTRE, R. Físico-química. Belo Horizonte: Editora Moderna, 2004.

FNS - Fiscalização e Segurança Nuclear. Relatório do grupo de trabalho - Câmara dos Deputados - Comissão de Meio Ambiente e Desenvolvimento Sustentável Brasília: FSN, 2007.

FRÖMAN, N. Marie and Pierre Curie and the discovery of polonium and radium. Palestra na royal swedish academy of sciences, em Estocolmo, Suécia, 1996. Disponível em: 〈http://nobelprize.org/nobel_prizes/physics/articles/curie/index.html> Acesso em 09.09.2010.

GABEIRA, F. Goiânia, rua 57. Rio de Janeiro: Guanabara, 1987.

GONDIN, K.C.P.; BORGES, L.B.; OLIVEIRA, E.C. (2008). Rir da desgraça alheia: o humor em tempos de césio. Disponível em: < http://www.prp.ueg.br/06v1/conteudo/pesquisa/iniccien/eventos/sic2008/fronteira/flashsic/animacao/VISIC/arquivos/resumos/resumo128.p df> Acesso em: 09.11.2012.

GOMES, P.C. Orientação sexual: vencendo preconceitos na sala de aula. Em: IV EIDE - Encontro Ibero-americano em Educação, CD-Rom. Universidade Estadual Paulista, UNESP - Campus Araraquara, 2009.

GREENPEACE. Os riscos da energia nuclear. 2010a. Disponível em :< http://www.greenpeace.org/Brasil/nuclear/raio-X-de-nuclear/os-riscos-da-energianuclear> Acesso em: 08.11.2011.

GREENPEACE. Verdades e perigos da energia nuclear. 2010b. Disponível em : <http://www.greenpeace.org/raw/content/Brasil/documentos/nuclear/verdades-eperigos-da-energia.pdf $>$ Acesso em: 08.11.2011.

GREENPEACE. Memorial césio-137. 2010c. Disponível em :

<http://www.greenpeace.org.br/nuclear/cesio/flash_cesio.html > Acesso em: 08.11.2011.

GREENPEACE. Grandes acidentes radioativos. 2010d. Disponível em :

$<$ http://www.greenpeace.org/Brasil/nuclear/grandes-acidentes-radioativos $>$ Acesso em: 09.11.2011.

GREENPEACE. 365 reasons to oppose nuclear power. 2010e. Disponível em : <http://www.greenpeace.org/raw/content/international/press/reports/nuclearaccidentscal endar.pdf $>$ Acesso em: 09.11.2011.

GSN - Global Security Newswire. NTI: Former U.K. officials urge global nuke disarmament. 30/06/2008. Disponível em: <http://gsn.nti.org/gsn/GSN_20080630_0858497C.php> Acesso em: 30.11.2011. 
HELENE, M. E. M. A radioatividade e o lixo nuclear. São Paulo: Scipione, 1996.

HENDRICHS, J.; ROBINSON A. (2009). To kill a pest: the use of radiation is improving the biological control of insect pests. Em: International Atomic Energy Agency, IAEA Bulletin, 5, 1,1, 34-38, 2009. Disponível em: <http://www.iaea.org/Publications/Magazines/Bulletin/Bull511/51105433438.pdf> Acesso em: 02.02.2012.

IAEAV - International atomic energy agency Vienna. The Radiological accident in Goiania. 1988. Disponível em: <http://wwwpub.iaea.org/MTCD/publications/PDF/Pub815_web.pdf> Acesso em: 05.02.2014.

INSTITUTO DE FÍSICA. Utilização da radioatividade. Universidade Federal do Rio de Janeiro. 2010. Disponível em:

< http://www.if.ufrj.br/teaching/radioatividade/utilizacao.html > Acesso em: 06.03.2014.

IPEN - Instituto pesquisas energéticas e nucleares. Centro de radiofarmácia. USP/CNEM, São Paulo - SP, 2006. Disponível em: <http://www.ipen.br/sitio/?idm=258> Acesso em: 08.04.2014.

KAMEL, C. R. L; LA ROCQUE, L. As histórias em quadrinhos como linguagem fomentadora de reflexões - uma análise de coleções de livros didáticos de ciências naturais do ensino fundamental. Em: Revista Brasileira de Pesquisa em Educação em Ciências. Belo Horizonte - MG, 6, 3, 59-76, 2006.

KRAFTWERK. Radio-activity [1975]. Side-one: "Radioactivity"/ "Radioaktivität" 6:42, digital, stereo, 1975.

LEITE, M.A.S.; ROPER, L.D.; The Goiânia radiation incident a failure of science and society. 1988. Disponível em: <http://arts.bev.net/roperldavid/gri.htm> Acesso em: 18.03.2014.

LIBERATION.FR. Obama, Sarkozy et Brown menacent l'Iran de sanctions «sévères»: Les trois dirigeants ont condamné l'Iran, qui a révélé aujourd'hui l'existence sur son territoire d'une deuxième usine d'enrichissement d'uranium. Journal Libération.fr. 2009. Disponível em: <http://www.liberation.fr/monde/0101593347-obama-sarkozy-etbrown-menacent-l-iran-de-sanctions $>$ Acesso em: 10.12.2010.

MARTINS, J. M. História da energia nuclear. Comissão Nacional de Energia Nuclear. 2007. Disponível em: 〈http://www.cnen.gov.br> Acesso em: 08.05.2014.

MARTINS, R.A. (1990). Como Becquerel não descobriu a radioatividade. Caderno Catarinense de Ensino de Física. 7, 27-45, Florianópolis - SC. Disponível em: <http://www.periodicos.ufsc.br/index.php/fisica/article/viewFile/10061/9286> Acesso em: 09.05.2014.

MARUMO, J.T.; SUAREZ, A.A. The determination of the cesium distribution coefficient of the interim storage soil from Abadia de Goiás, GO, Brazil. Em: Waste Management, 10, 2, 111-115, 1990. 
MASCANZONI, D. Long-term ${ }^{137}$ Cs contamination of mushrooms following the Chernobyl fallout. Em: Journal of Radioanalytical and Nuclear Chemistry, 249, 1, 245-249, 2001.

MME. Ministério de Minas e Energia, Plano nacional de energia 2030. Colaboração empresa de pesquisa energética. Brasília: MME, 2007.

MEC. Ministério da educação e cultura, secretaria de educação básica. Orientações curriculares para o ensino médio: ciências da natureza, matemática e suas tecnologias. volume 2, Brasília: MME, 2006.

MEC. Ministério da educação, secretaria de educação média e tecnológica (Semtec). PCN+ ensino médio: orientações educacionais complementares aos parâmetros curriculares nacionais - ciências da natureza, matemática e suas tecnologias. Brasília: MEC/Semtec, 2002.

MEC. Lei de diretrizes e bases da educação nacional. Lei n ${ }^{\circ}$ 9.394/96 de 20 de dezembro de 1996. Estabelece as diretrizes e bases da educação nacional. Diário Oficial da União. Brasília: Imprensa Nacional, 1996.

MEIGIKOS DOS ANJOS et al. Estudo do acidente radiológico de Goiânia no ensino de física moderna. Revista Brasileira de Ensino de Física, 22, 1, 60-68, 2000.

MERÇON, F.; QUADRAT, S.V. A radioatividade e a história do tempo presente. Revista Química Nova na Escola, 2004. Disponível em: <http://qnesc.sbq.org.br/online/qnesc19/a08.pdf> Acesso em: 11.12.2011.

MORTIMER, E. F.; MACHADO, A. H. Química para o ensino médio. 398 p. São Paulo: Scipione, 2000.

MOZETO, A.A.; JARDIM, W.F. A química ambiental no Brasil. Em: Química Nova, $25,1,7-11,2002$.

NOUAILHETAS, Y. Radiação ionizantes e a vida. Comissão Nacional de Energia Nuclear.2007. Disponível em: 〈http://www.cnen.gov.br> Acesso em: 01.12.2011.

OLIVEIRA, E.C. As representações do medo e das catástrofes em Goiás. Tese de Doutorado, 359 p., Universidade de Brasília, 2007.

PAVÃO, A.C. Ensinar ciências fazendo ciências. Em: Pavão, A.C. \& Freitas, D. (Org.), Quanta Ciência Há no Ensino de Ciências. (pp. 15-24) São Carlos: EdUFSCar, 2008.

PASACHOFF, N. Marie Curie and the science of radioactivity. Oxford New York: University Press, 1996.

PIRES, R.; CARVALHO, L.A. Césio 137: O pesadelo de Goiânia. [filme-vídeo]. produção de Luiz Antônio de Carvalho, produção executiva de Laura Carneiro, direção de Roberto Pires. São Paulo - SP, Master Cinevideo Produções Ltda. 1 cassete VHS/PAL-M, 115 min. color. Som, 1990. 
PINTO, F.A. A menina que comeu césio. Brasília: Ideal, 1987.

PIZARRO, M.V. Histórias em quadrinhos e o ensino de ciências nas séries iniciais: estabelecendo relações para o ensino de conteúdos curriculares procedimentais. Dissertação de Mestrado, UNESP/Campus de Bauru - SP, 2009.

QUINN, S. Marie Curie: uma vida. São Paulo: Scipione, 1997.

RABONI, P. C. A. Atividades práticas de ciências naturais na formação de professores para as séries iniciais. Tese de Doutorado, UNICAMP, Campinas, 2002.

SABATINI, R. Economic sanctions: pressuring Iran's nuclear program, Monterey Institute for International Studies, James Martin Center for Nonproliferation Studies. 2010. Disponível em:

$<$ http://www.nti.org/e_research/e3_economic_sanctions_pressuring_iran_nuclear_progr am.html> Acesso em: 18.12.2010.

SANTOS, R. O acidente radiológico de Goiânia. Comissão Nacional de Energia Nuclear. 2007. Disponível em: 〈http://www.cnen.gov.br> Acesso em: 18.11.2012.

SOUZA CRUZ, F. F. Radioatividade e o acidente de Goiânia. Caderno Catarinense de Ensino de Física, 4, 3, 164-169, 1987.

SILVA, T.C. As celebrações, a memória traumática e os rituais de aniversário. Revista Universidade Federal de Goiás (UFG)-Dossiê Césio-137, 2007. Disponível em: <http://www.proec.ufg.br/revista_ufg/agosto2007/textos/dossieCelebracoes.pdf> Acesso em: 18.10.2012.

SEMO, M. (2010). Start: les réducteurs de têtes nucléaires - Traité: Obama et Medvedev ont signé hier un accord réduisant leur armement non conventionnel. Em: Libération.fr, Cahier monde, 2010. Disponível em: < http://www.liberation.fr/monde/2010/04/09/start-les-reducteurs-de-tetesnucleaires_619905 > Acesso em: 18.04.2014.

TAKANO, K. Prevention of internal exposure to cesium-137 $\left({ }^{137} \mathrm{Cs}\right)$ radiation in inhabitants of an area contaminated by the Chernobyl accident. Em: Environmental Health and Preventive Medicine, 28-32, 1996.

VERGUEIRO, W. et al. Como usar história em quadrinhos na sala de aula. São Paulo: Contexto, 2004.

VERGUEIRO, W.; RAMOS, P. Quadrinhos na educação: da rejeição à prática. 224p. São Paulo: Contexto, 2009.

WASCHECK, C. C. História do acidente radioativo de Goiânia. Em: Governo do Estado de Goiás, Secretaria de Saúde do Estado de Goiás. Superintendência Leide das Neves Ferreira - SULEIDE. 2007. Disponível em: < http://www.sgc.goias.gov.br/upload/links/arq_254_historiadoacident.pdf > Acesso em: 19.04.2014. 
WASSERMAN, M.A.; PEREZ, D.V.; BOURG, A.C.M. Behavior of Cesium-137 in some Brazilian Oxisols. Communications in Soil Science and Plant Analysis, 33, 7-8, 1335-1349, 2002.

WEBBER, Andrew Lloyd. Pie jesu [1985]. Em: Requiem; Domingo, Placido;

Brightman; Sara; Maazel, Lorin - 4:40, digital, stereo, 1985.

WEISEL, Eli. O canto dos mortos. Porto Alegre: Livraria Cultura, 2003. 